DOI: doi.org/10.21009/IJLECR.061.01

Received: 28 March 2020

Revised: 6 June 2020

Accepted: 18 June 2020

Published: 30 June 2020

\title{
ENGLISH SPEECH ACTS OF DIRECTIVES IN CLASS INTERACTION
}

\author{
Bahing Siritman ${ }^{1, a)}$, Mayang Meilantina ${ }^{2, b)}$ \\ Palangka Raya University (UPR), Faculty of Teacher Training and Education, \\ Department Language and Art, English Study Program \\ Hendrik Timang Street, Palangka Raya, Central Kalimantan, Indonesia ${ }^{1)}$ \\ Palangka Raya University (UPR), Faculty of Agriculture, \\ Department of Agricultural Social Economics, Agricultural Economy Study Program \\ Hendrik Timang Street, Palangka Raya, Central Kalimantan, Indonesia ${ }^{2)}$ \\ bahing@edu.upr.ac.id ${ }^{\text {a) }}$, mayangparay@gmail.com ${ }^{\text {b) }}$
}

\begin{abstract}
This research was highly concerned with the study's ethnography of communication, i.e., in the way of speaking a language. The objective was on learning realization of English speech acts in the class interaction between students and lecturer(s). The study conducted in the English Education Study Program of Palangka Raya University. The method applied was a communication ethnography based on empirical facts' social phenomena in terms of illocutionary speech acts of directives. It is qualitative research focusing on the speakers' utterances. Data collected using Spradley's ethnography method. Data analysis using the model of Hymes' communication analysis, including analysis of communication situation, communication events, communication acts, and Spradley's analysis of cultural theme. The first finding and the novelty showed that the realization of the directive speech act had been the most dominant one. This finding proved that the illocutionary speech act of directives has a higher social status in an interaction. The use of speech acts of directives proved that it was strictly related to the context of the situation and culture of the speaker(s). In contrast, the higher(s) had dominated, the lower(s). Finally, the directive speech act was used to control the class to be interactive by the lecturer(s).
\end{abstract}

Keywords: Speech Act of Directive, Class interaction, Ethnography of Communication

This research was highly related to English speech acts of directives in the class interaction. The speech act is one of the language skills that are very functional, observable, workable, concrete and empirical. The speech act is a "locomotive" to move a language or as a "trigger kit" to make a language functional in communication. The speech act is an utterance used by a speaker to make a piece of spoken language or an ability to talk to convey, to promise, to ask, to demand, to request, to deny, to report, to complain, and to announce. It is a basic functional unit in communication, and it is the nature of language as a means of communication and interaction among people in the world.

Thereby, it is a 'state of the art' in this research because the speech act is regarded as a locomotive or as a trigger kit in communication. Communication is nothing without speech act since speech act make a direct communication to the speaker(s) and hearer(s). The speech act is an utterance used by a speaker to make a piece of talking or discourse, and it is used to convey, to promise, to ask, to demand, to request, to deny, to report, to complain, and to announce. It is a basic 
functional unit in communication, and it is the nature of language as a means of communication and interaction among people in the world. So, however, it is the 'State of Art' of direct communication among people.

It is related to research reports that the teaching of speech act theory has become increasingly imperative, and speech act theory plays its significant part in EFL teaching and learning (Zhao \& Throssell, 2011). This means that a speech act is a must in speaking a language. This is one of the rational reasons why I had done this research. The differences were on the focus of research, whether on the version of Austin and Searle. More than that, the research above did not focus on a specific classification, such as locution, illocution, and perlocution.

In terms of the significant finding of this research, it was found that the illocutionary force of the directive speech act is the 'Novelty' of this research. It was the 'Novelty' of this research since the illocutionary speech act of directive was the most significant finding. Directive speech act has a high social status in an interaction. A person with a high social status would use this directive speech act to communicate with the lower(s) social status. Thereby, it was the 'Novelty' found in this research.

When compared with the previous studies implemented by Zhao \& Throssell, (2011), it is identified that there was a big gap between these two kinds of research. In that research, there was not recognized a novelty found there; it was only research of EFL teaching and learning. So thereby, there was a big gap found between these two kinds of research.

The author wanted to synthesize that this research was significant enough in line with the directive's application and use of illocutionary speech acts. The high social status of the illocutionary speech act of directive was considered as the novelty of this research since it was the most significant finding. The use of this directive speech act was in concern with the context of situation and social-culture in society. The speech act was regarded as the locomotive and trigger out the language to be communicative, and it is a functional one. Functional means meaningful, interactive and it is useful. It is because meaning is determined by its contexts of situation and culture of the society. Thereby, this was the synthesis of this research that becoming a burning issue of conduct. This has made the study was significant, and to be interested in conduct.

As a system, a language has a direct relation to a speech act, and they work collaboratively in a functional network system, that I named it "an integrated functional network system." This indicates factually that a language works in a speech act silently to produce utterance, and utterance is as a means of communication. Shortly speaking, speech or utterance is considered as a real means of functional communication.

A language works in a "silent network system" through the cognitive domain to produce a concrete, observable and empirical speech or utterance. The speech or utterance functions as a means of social communication for working and interacting. Next, this system works in a speech act called the "speech act network system" through the human speech organs to produce speech or utterance as a means of functional communication. Shortly speaking, a language works silently through speech acts to produce speeches or utterances (concrete and observable) for working and interacting. In conclusion, the nature of a language is the "Speech Act," a basic functional unit.

This notion was based on an International Journal explication, where it expressed that "people do actions through speech and utterance." In other words, it said that "people do not produce the grammatical utterances and words merely to express themselves, they perform actions via these utterances (Shams, \& Afghari, 2011)

A speech act is "an utterance as a functional unit in communication." A speech act is one of the language aspects that functional, concrete, and observable. A language is abstract, while speech or utterance is observable through the perspective of speech organs and its act of communication. This concept plays its prime role in this research (Richards and Platt \&Platt, 1992). 
The speech act classifications comprise two (1) constative speech acts and (2) performative speech acts. The performative one was classified by Austin, 1962, into (1) locutionary act, (2) illocutionary act, and (3) perlocutionary act. Conceptually, this notion is following the research report stated by Utami et al, (2013). The difference to this research focused on the speech act of the "Expressive Speech Act of Judges Narratives." The significant distinction was that their research focused on language politeness of Brown-Levinson's theory. At the same time, mine was related to the realization and the hit of the maxim of the cooperative principle of Grice's theory.

Therefore, I also needed to base this research on a closely related theory of the focus and sub-focuses. Thereby, I referred it to the basic theory of speech act as initiated by Austin, 1962. Formerly, speech acts were classified into (1) constative, and (2) performative (Chris Uchenna, 2008). However, the research conducted by Chris Uchenna was oriented to speech act analysis of political discourse, implementation of the direct and indirect speech act in Mata Najwa talk shows on Metro TV (Tressyalina \& Ridwan, 2015). They are not on the realization of English speech acts in-class interaction. The significant differences were that my research was related to language learning and language teaching, while his research was on the political discourse of a public domain.

Speech act has advanced significantly in pragmatics. Pragmatics studies speech acts in the context of social cultures. However, pragmatics itself cannot afford to manage speech act without the involvement of discourse" for both of them are closely related (Dylgjeri, 2017).

Dylgjeri stated that pragmatics could not be adequately studied without considering discourse analysis since they are closely linked with each other. The distinction of the research was on the focus of the study about the speech act is the object of central pragmatics (Akinwotu, 2013). This study was about the relationship of speech act as a strategic means of people mobilization in a political campaign for president election. These studies own similarity to mine in terms of illocutionary acts. The studies were in line with the realization of the speech act in English class interaction to get a deep understanding.

Furthermore, pragmatics is the object study of discourse for pragmatics is in discourse. Pragmatics studies speech acts in the context of the situation and social cultures. In contrast, discourse studies the context of the sentence in texts, and text is discourse. Discourse is a text larger then sentence and it is the larger unit of language, i.e., paragraphs, conversations, interviews. Discourse is a general term for language use, i.e., the language which has been produced as the result of an act of communication (Richard and Platt \& Platt, 1992) Discourse can be spoken or written, dialogic or monologic, and it would be a text whenever analyzed, called discourse analysis.

This research was initiated from the pre-identification of a social and empirical phenomenon in the students' circumstances. That phenomenon was in concern with a hit of the maxims of cooperative principles in speaking of Grice's theory (Grice, 1989). Interestingly, that phenomenon occurred in the students' circumstances of the language department. This fact attracted my curiosity to know profoundly and get information about the roots of the problem. Further, this problem has never been investigated in academic research, particularly in the English Education Study Program, Palangka Raya University. However, in this article, the writer did not include the hit of Grice's maxims. The writer only included the focus of English speech acts and the sub-focus of the illocution speech acts.

The speech act is a complete language unit that consists of skills and components. It is part of language skill for it is spoken and uttered. However, it is non-language components since it involves a speaker, topic, goal, messages, and contexts of situation and cultures. Speech acts and utterances derive from the non-linguistic study, but it is part of social cultures, and it is an object of pragmatics (Al-Hindawi et al, 2014). A basic unit of communication is speech act or utterance. When doing communication, one will make speech or utterance, and that speech is "a functional 
communication unit." This explication has been confirmed in Austin's underlying theory that "speech act is an utterance as a functional unit in communication" (Richards and Plat \& Platt, 1992: 342).

This research was also due to the theory of Dell Hymes, 1989 in "Ways of Speaking" (Hymes, 1989:4). Muriel Saville-Troike: "The Ethnography of Communication" (Troike, 2013: 23) and Grice's theory (Grice, 1967). The method and procedures applied were due to Hymes' theory of communication ethnography in 1989 and developed by Muriel Saville-Troike, 2003, in "Ethnography of Speaking." Next, I related it to Grice's theory of "maxims of cooperative principles in ethnography of speaking." This Grice's theory of the maxims of cooperative principles of speaking was one of the sub-focuses of this research

Other theories applied in this research were a pragmatic theory, for speech act is studied in pragmatics and discourse as stated by (Dylgjeri, 2017) and developed by George Yule (2010: 133). Dygjeri stated the speech acts theories have been a considerable revolution in the development of pragmatics as a discipline. However, pragmatics cannot be adequately studied without taking into consideration discourse analysis, since they are closely linked with each other

Based on the research on the pragmatic theory developed by a linguist, Geoffrey Leech, 1993. In methodology, the writer accommodated the theory of ethnography of communication model by Hymes (1989), then completed through the theory of the communication model's ethnography by Muriel Saville-Troike (2003). The writer also added a theory of Schiffrin (1994) dealing with the explanation of "SPEAKING Grid" and the theory of ethnography research (Spradley, 1980). However, I also applied Grice's maxims of cooperative principles in speaking analysis and Spradley's procedures to collect the data, such as observation, recording, interview, transcription, field notes, and the documentation.

\section{METHOD}

This research was considered social research based on language speakers, which means that it was related to people's culture in communication. Since this research was related to the ways people use a speech act, thereby the method used was ethnography of communication stated by (Hornberger 2009).

In line with the scope of research, thereby the size of research was simplified to be a micro ethnography research. This research was focused on the language education of the English Study Program. The focus of investigation concerned English Speech Acts in the class interaction conducted in the English Education Study Program, Palangka Raya University of the Centre of Borneo-Kalimantan. In particular, the sub-focus only included the illocutionary speech act of the directive one. The applied approach was qualitative since it was related to the behavior of doing communication through speech acts; the data needed to be data of narrative-descriptive.

The procedures of collecting the data, the writer referred to Spradley's theory in terms of ethnography research based on field research or fieldwork. The procedures involved (1) observation, (2) recording, (3) interview, (4) transcription, and (5) documentation or field notes.

This research-based on the communication ethnography, and that is why the writer dealt with the theory of Hymes in communication, particularly on the analysis of communication. This theory was also developed further by Muriel Saville-Troike in concern with the steps and procedures, i.e. (1) analysis of communication situation, (2) analysis of communication events, and (3) analysis of communication activities. However, I needed to say that the ethnography of Spradley, which consisted of (1) domain analysis (2) componential analysis, (3) taxonomy analysis, and (4) cultural themes analysis, were also used. But in this study, the writer only conducted the Hymes' analysis and Spradley's analysis of the cultural themes to make it simpler.

The elicited data were field data, such as observation, interaction records, transcriptions, 
interviews, and documentation such as photos, video film, and field notes. The data resources were elicited from the interaction of lecturers and students in several interactive classes through live event interaction. The collection of data using triangulation to make it valid, as well as possible. In the triangulation process, the writer applied the procedure such as camera, video/film, field notes, and class interaction notes. The writer used a camera to make it live to set, and by using camera and video/film, it could be repeated

\section{RESULTS AND DISCUSSION}

The research has produced a lot of speech events (51). After an analysis of data, it was identified that eleven (11) of speech events failed to be done. This failing was because the students never learned how to carry out the speech act for interaction; their achievement was still "good" due to the scoring index of $78.431 \%$. The number of illocution speech acts of the directive was 105 utterances used by the lecturers; the number of illocution speech acts of representative-assertive was 90 utterances used the students.

The research found that (1) the realization of directives' speech acts in an interactive class has been conducted "good," where students actively participated in their contribution of interaction. The significant finding proved that the illocution speech act of directive had become the dominant one in that interaction. (2) the lecturer(s) mostly used the illocution speech act of directive one. This fact provided an interpretation that the illocution speech acts of directive one play the most significant roles in that interaction. This interpreted that this illocution speech act of directive has higher social status than other classifications. This was the most significant finding of the research, and this was considered the newness of the research. This finding interpreted that the speech acts of illocution of directives have high social status in an interaction. (3) The finding proved that the use of speech acts such as the illocution speech act of directive was strictly related to the context of the speaker's social status (s). This indicated that higher social status had dominated the lower(s). (4) this was identified through the use of directive speech acts. It meant that the directive speech act has higher social status than other classes of speech acts. In conclusion, the higher social status in an interaction proved to apply the illocution speech act or directive rather than other classifications of speech acts. (5) The illocutionary speech act of directives was dominant by lecturers since lecturers made requests, asks, give comments, questions made appreciation during the session. While students only said yes or no, and some time comments. (6) Lecturers used speech acts of directives to control the class interaction. To make the class interactive, the teacher applied the illocutionary speech act of directives.

The research finding indicated that the illocution speech act of directive had become the most dominant one. In contrast, the illocution speech act of representative-assertive one became the second dominant one. In this research, I proposed an illocutionary speech act of directive one. This finding indicated that lecturers and students could conduct class interaction through a dialogue of questions and answers. In other words, the class was active- interactive, and they exchanged speech acts through turn-taking organization. Turn-taking is an organization in speaking because we cannot do an interaction directly while everybody is speaking together at the same time. Thereby, there must be the hearer(s) and the speaker(s).

In this finding, students were active in giving contributions as well as possible (Ma, X. (2016). Students were active in giving and demanding by exchanging goods, services, and information. They were active in expressing ideas and opinions, but they never used the illocutionary speech act of directive. They used other types of speech acts, such as representativeassertive, expressive, commissive, and declarative. The illocutionary speech act of directives was used by the lecturer(s) to keep talking and controlled the class.

The research showed that the lecturer's directive speech acts dominated the class interaction. 
The significant finding proved that the use of speech acts of the directive was strictly related to the context of the social status of the speaker(s). During the session, it emphasized that the higher(s) social status had dominated, the lower social status ie, the lecturer and the students. The speaker with higher social status used illocutionary speech acts of directive one to control the class. This was a significant finding of this research.

The illocutionary speech act of directive was very dominant by the lecturer(s) because they used this speech act of directive to control the class and expressed their opinions. Directive speech act was found a dominant one in that interaction since lecturer(s) were involved in that class interaction. This directive speech act was closed to a high social status, and it was used to ask, to request, to demand, to give, suggest, to advise. This directive speech act was regarded as high social status, and this was found in the context of the situation, society, and cultures of the speakers. This directive speech act was a novelty of this research, and it was a significant one.

The realization of direct and indirect speech acts has been established well enough. This had been proven through the use of question intonation, question words, interrogatives, and verbal verbs. Istiningdias et al. (2014). Stated the direct speech act to refer to the clause in which the mood of the clause matches the speaker's intent in this way. Indirect speech act mood and the speaker's intent do not always match. The most significant finding of this research was that of the directive speech act. It was regarded as one of the higher speech act classifications when compared to other classification since the lecturers dominantly used it in that class interaction. It meant that this directive speech act had a higher class of social status since the lecturer(s) used this speech acts in that class interaction. The teacher (s) used this speech act to control the class and to manage the class in order for the class interaction could run smoothly. While students applied other types of speech acts, such as (a) assertive, (b) commissive, (c) expressive, and (d) declarative, but these classifications of speech acts were not proposed in this occasion.

Thereby, it is state of the art in this research because the speech act is regarded as a locomotive or as a trigger kit in communication. Communication is nothing without speech act since speech acts make direct communication to the speaker(s) and hearer(s). A speech act is an utterance used by a speaker to make a piece of talking or discourse, and it is used to convey, to promise, to ask, to demand, to request, to deny, to report, to complain, and to announce. It is a basic functional unit in communication, and it is the nature of language as a means of communication and interaction among people in the world. So, however, it is the 'State of Art' of direct communication among people.

This research was related to Grice's maxims theory. However, in this article, it was not included. Speech acts in terms of Grice's maxims were cooperative Principles; Grice subdivided this general principle into the more detailed maxims (Xiaoyu, 2016). There are four maxims: Quantity Maxim, Quality Maxim, Relation Maxim, and Maxim Manner. This would be involved in the written research report.

I wanted to synthesize that this research was significant enough in line with the application and use of illocutionary speech acts of the directive. The high social status of the illocutionary speech act of directive was considered the novelty of this research since it was the most significant finding. The use of this directive speech act was in concern with the context of situation and socialculture in society. The speech act was regarded as the locomotive and trigger out of the language to be communicative; it is a functional one. Functional means meaningful, interactive and it is useful. It is because meaning is determined by its contexts of situation and culture of the society. Thereby, this was the synthesis of this research that becoming significant and interested in conduct.

\section{CONCLUSION}

The object of research was illocutionary speech acts of directives. The finding proved that 
the illocution speech act of directives dominated an interactive class. The speech act of illocution has become a "must" in a system of functional communication. This means that the existence of language is in the speech act and the nature of language is a speech act. The finding data showed that the realization of the illocutionary speech act of directives had been established in good mastery.

They referred to the data finding of research that the illocution speech act of directive one has been the most dominant one. It was followed by the illocution speech act of representativeassertive one. This finding was because the lecturer(s) mostly applied the illocution speech act of directive one. This finding provided an interpretation that the illocution speech acts of the directive have a higher social status than other speech act classifications. Lecturer (s) kept control of the class by using the illocution speech act of directive. At the same time, students were not confident to apply this type of illocution speech act. In this case, the students only used directive speech acts when they were forced by the lecturer(s) to give questions.

The finding of this research showed that the competence of the participants was not satisfactory yet. This unsatisfactory competence, since students never learned the use of speech acts in an interaction explicitly. Thereby, it was recommended that the English Education Study Program introduce the aspect of speech acts as one of the materials of speaking skill courses. The knowledge of speech acts is considered essential to be taught to students, especially the illocutionary force. It is in line with the nature of language as a means of communication. As a means of communication, a language is represented by a speech act, because the speech act is a basic unit in functional communication. Thereby, the teaching of speech acts, especially the illocutionary force, was considered as "a must."

\section{REFERENCES}

Agbedo, U. C. (2008). A Speech Act Analysis of Political Discourse in the Nigerian Print Media. Ikenga International Journal of African Studies.

Ahidjo, E. (2010). Doing Things with Words: A Speech Act Analysis of a Christian Wedding. An International Multi-Disciplinary Journal, Ethiopia.

Akinwotu, A. S. (2013). A Speech Act Analysis of the Acceptance of Nomination Speeches of Chief Obafemi Awolowo and Chief M.K.O. Abiola. International Journal on English Linguistics Research, Adekunle Ajasin University, Nigeria. URL: http://dx.doi.org.,/10.35430/elr.v2nI p. 43-49

Altikriti, F. S. (2011). Speech Act Analysis To Short Stories. The International Journal of Language Teaching and Research, Finlandia: Dept. of English Language, Al Isra University, Amman, Jordania.

Austin, L. J. (1962). How To Do Things With Words. Oxford-UK: At the Clarendon Press.

Deborah, S. (1994). Approaches to Discourse: Blackwell Publishing: 238 Main Street, Cambridge, Massachusetts-USA.

Dylgjeri, A. (2017). Analysis of Speech Acts in Political Speeches. International Journal on European Journal of Social Science Studies, at Elbasan University, Albania. Available on-line at: WWW.oapub.org/soc,

Emike, J. A. (2013). The Illocutionary Frames Principles (IFP) and the Austinian Postulations: A Clause-Structure Investigative Discourse. Global Journal of Human Social Science: Linguistics \& Education, Global Journal Inc. USA. Ajayi Crowther University, Nigeria.

Grice, H. P. (1967). Logic in Conversation: California: by Harvard University Press.

Hindawi, H. Fareed, Masudi, H. Hammed \& Mirza, F. Ramia. (2013). The Speech Act Theory in English and Arabic. International Journal of Modern Linguistics: at English Department College 


of Education for Human Sciences University of Babylon, Iraq.
http//dg.dol.org/10.4236/ojml.41003.

Hymes, D. (2009). Hymes's Linguistics and Ethnography in Education. Journal of Graduate School of Education, Penn Libraries: University of Pennsylvania, Scholarly Commons.

Hymes, D. (1989). The Ethnography of Communication: Carnegie Mellon University, Pittsburgh PA, USA.

Istiningdias, S., Dini, S., TS. Eva \& Indrayani, M. L. (2014). Illocutionary Acts In Declarative Mood: A Functional Grammar Approach. International Journal of English and Education: English Linguistics, Faculty of Humanities, Universitas Padjadjaran, Bandung Indonesia.

Jabber, W. K. and Jinquan, Z. (2013). The Modal Verbs: A Speech Act of Request in the Speech of the President of the United States, Barak Obama. An International Journal in English of English Department: Misan University-Iraq, English Department: Huazhong University-Wuhan, China.

Leech, G. (1993). The Principles of Pragmatics: The Longman Group, Ltd., University of Lancaster-UK.

Ma, X. (2016). A Case Study on Characters in Pride and Prejudice: From Perspectives of Speech Act Theory and Conversational Implicature. International Journal of English Linguistics, 6(4), 136-143.

Paul H. G. (1999). Studies in the Way of Words: Harvard University Press: Cambridge, Massachusetts, London-England.

Richards, J. C., and Platt \& Platt. (1992). Dictionary of Language Teaching \& Applied Linguistics: Longman Group, UK Edinburgh, England.

Searle, J. (1969). Speech Acts: An Essay in the Philosophy of Language: Cambridge: Cambridge University Press.

Spradley, P. J. (1980). Participant Observation: Orlando, Florida: Harcourt Brace Jovanovich Inc.

Shams, R., and Afghari, A. (2011). Effects of Culture and Gender in Comprehension of Speech Acts of Indirect Request". International Journal on Department of English, Islamic Azad University-IranURL: http://dx.doi.org /10.55.39/elt.v4n4, p. 279-283

Troike-Saville, M. (2003). The Ethnography of Communication: Blackwell Publishing: Oxford, UK.

Utami, W. P., W. Darmayanti, N., and Riyanto, S. (2013). Expressive Speeach Act of Judges' Narratives in X-Factor Indonesia Talent Show on Rajawali Citra Televisi Indonesia: A Pragmatic Study. International Journal of Language Learning and Applied Linguistic World (IJLLALW).

Shams, R., and Afghari, A. (2011). Effects of Culture and Gender in Comprehension of Speech Acts of Indirect Request. English Language Teaching, 4(4), 279-287.

Tressyalina, T., and Ridwan, S. (2015). Speech Act In An Indonesian Television Talk Show (Content Analysis Research In Mata Najwa Talk Show At METRO TV). IJLECR-International Journal of Language Education and Culture Review, 1(2).

Yule, G. (2010). The Study of Language: Fifth Edition: Cambridge, New York: Cambridge University Press.

Zayed, M. N. (2014). Jordanian EFL Teachers' and Students' Practice of Speech Acts in the Classroom. International Journal on Studies in English Language and Literature (IJSELL), American University in the Emirates (AUE). www.arcjournal.org, p. 1-5.

Zhao, Y., and Throssell, P. (2011). Speech Act Theory and Its Application to EFL Teaching in China. The International Journal on Language Society and Culture: At: www.educ.utas.edu.au/users/tie/ Journal/ISSN 327-774X: URL: p. 88-92 